\title{
Influence of Academic Staff Empowerment on Service Delivery in Nigerian Universities
}

\author{
Dr. Olayemi J. Abiodun-Oyebanji \\ Department of Educational Management, Faculty of Education, University of Ibadan, Ibadan, Nigeria
}

\begin{abstract}
This paper examined the influence of academic staff empowerment on service delivery in Nigerian universities. The paper adopted the descriptive survey research design and the population comprised all the academic staff of both the University of Ibadan and Lagos State University; Nigeria, while simple random sampling technique was adopted to select 150 academic staff from each of the sampled universities respectively, this made a total of 300 academic staff. The research instrument used for the study was a questionnaire titled "Academic Staff Empowerment and Service Delivery in Nigerian Universities, ASEASD" with a reliability value of 0.82 . Four hypotheses were formulated and tested. Multiple regression and Independent T-test were used to test hypotheses one and two and three and four respectively. The results showed that, training, promotion, incentive, job recognition and job security jointly contributed to service delivery in Nigerian universities. However, Job recognition is a more potent predictor. The results further indicated that, there was a significant difference between academic staff empowerment in federal and state universities. The results equally revealed a significant difference between service delivery in federal and state universities. Based on the findings of the study, it was therefore recommended that university management should not only recognize the job of academic staff but should also identify those who deserve promotion as well as incentives and accord them appropriately, for better service delivery. Continuous efforts should also be put in place by universities management to ensure academic staff empowerment for better service delivery.
\end{abstract}

Keywords: Academic Staff, Empowerment, Service Delivery, Nigerian Universities

DOI: $10.7176 / \mathrm{JEP} / 10-3-12$

\section{Introduction}

The place of employees' service delivery in the attainment of organization goals and objectives cannot be underplayed. This is because the expected quality of performance of staff within an organization must be in line with the aims and objectives of such an organization; otherwise the achievement of organization aims and objectives may be jeopardized. Service delivery is basically and fundamentally concerned with the end product of the combination of all the inputs made in a given job. It is an extent to which an individual, unit or department of an organization discharges its assigned or statutory responsibilities, and it is a means by which an organization evaluates an individual employee or unit inputs and output level especially in the area of attaining set goals or task assigned. In the view of Byars and Rue (2006), it is the degree to which an employee accomplished the tasks that made his or her job.

El-Rufai (2013) likewise sees service delivery as the degree of an organization and/or employee's performance, output and productivity, as helshe discharges his responsibilities within the available time, money and other resources, towards the achievement of overall goals of the organization. The spate of service delivery is therefore determined by the performance of employees' in achieving the organizational goals and satisfying the public. It is a continuous cyclic process for developing and delivering user-focused services.

Academic staff service delivery in Nigerian universities can therefore be described as the quality of performance expected of an academic staff within the university system. It is the academic staff efficient and effective performance of their cardinal functions of teaching, research and community service, all geared towards the achievement of the visions and missions of their universities. Every profession has its variables of measuring the quality and quantity of service delivery, and this to a very large extent determine the level of the output made or produced. In contemporary Nigerian universities, academic staff service delivery is usually measured through teaching, research and community service. It is therefore evident that the quality of graduates produced in any universities, the ranking profile of such universities and even the status of the academic staff are determined among others by the degree of services delivered by them.

According to the Nigerian National Policy on Education (2014), the major purpose of university education in Nigeria is to contribute to national development. Sunday (2017) laid credence to this that, the development of any country is largely dependent on the rate of investment in education. Not just any education, but institutions of higher learning, (university inclusive). The success of any university system is majorly among others depends on the academic staff that play vital roles in the course of achieving the goals therein, it is important therefore that academic staff are armed with all the necessary tools to enhance their effectiveness in the performance of their duties.

Upev and Idachaba (2015) stated that universities are like every other complex system comprising many 
subsystems which must work together in harmony for the attainment of its goals. These systems are composed of employees, among which are academic staff, it is important that they are empowered to effectively deliver their required services as and when due. According to Ayeni, Jaiyeoba and Atanda (2008), academic staff in Nigerian universities are saddled with the delivery of three major services; teaching, research and community service like their counterparts in other parts of the world. The extent at which these services are delivered determines the level of knowledge acquired by the students, the level of research work carried out by members of the academia to solve societal problems and also the rate at which community development projects and services are embarked upon all for the benefit of the larger society (Abiodun-Oyebanji, 2010).

However, the service delivery of academic staff of many Nigerian universities seems to have become a matter of great concern to stakeholders in recent time because of the critical roles these cadre of staff play in the realization of goals, objectives, mission, visions and overall quality of university education via effective teaching, research and community activities. Universities hence depend on the intellectual, creative and performance of their academic staff to realize these goals. Adelekan (2018), laid credence to this that, academic staff are to disseminate information to students and this in turn does increase knowledge acquisition both for themselves and the students they teach. This process of teaching and learning leads to the production of quality graduates for manpower development. Likewise, the quest for new discoveries, innovations and inventories (Research) do help project or enhance the university standard. This then makes it imperative for university management to ensure that academic staff are well empowered for a better delivery of their services.

Despite the essentiality of these three cardinal functions of academic staff, it seems there is a major decline in the qualities of teaching, learning and research going on in the Nigerian universities system. Most public and private employers of labour seem to have lost confidence in the graduate of Nigerian universities. AbiodunOyebanji (2014) affirmed this, that there is a kind of mix- match between Nigerian universities graduates and labour market requirements. This may not be totally divorced from assumed defective curriculum, poor teaching and research going on in many Nigerian universities due to the perceived failure of the system, which bothers down on the poor funding of the university system, which had invariably degenerated to poor infrastructural facilities in many Nigerians universities over the years.

Apart from the failure in teaching and research activities in many Nigerian universities, community service which is the third area of service delivery of academic staff appear to have been totally neglected by many Nigerian universities lecturers. It seems there is no cordial relationship between town and gown any more. This aspect of academic staff service delivery seems to have become totally passive or gone comatose. Things appear so bad for this third function of academic staff because lecturer's promotion in many Nigerian universities is until recently when teaching was included, is based mainly on their research productivity. Community service has never been part of academic staff promotion criteria.

However, the assumed poor service delivery of academic staff could also be attributed to failure of many universities management to adequately empower their work force, most especially the academic staffs which are the life-wires of the system, with necessary tools that could enhance their performance. Empowerment triggers the motivational spirit of an employee, thus, it is seen as a motivational concept which sees to the improvement of employees self-competence. Lowe (2001) sees empowerment in the public service (university system inclusive) as dismantling the bureaucratic structure in favour of a more flexible organizational structure. It does not only affect workers attitude to work but also affects their performance (i.e managerial effectiveness and employee productivity/ performance) and work behaviours (i.e innovation, upward influence and being inspirational to others).

According to Akinwumi (2000), empowered workers (team) are likely to show positive outcomes, have better process improvement, display high quality services, are more proactive, are less resistant to change, more satisfied with their jobs, and committed to the team and organization. Empowerment is especially important in organizations (such as university) where people must work independently. For academic staff of Nigerian universities to effectively perform their cardinal roles of teaching, research and community service as stated in National Policy on Education (NPE, 2014), there is a need for them to be adequately empowered since organizational success or failure and performance is a function of many factors among which is employees' empowerment (Awamleh, 2013).

Clutterbuck (1994) argued that empowerment would help individuals to gain more control over their working environment, enhancing their contributions and taking opportunities for personal growth and invariably, improved service delivery. It would also enable workers to perform well in their roles, making them more independent and able, increasing their confidence and willingness to be visible. In the words of Abosede (2013), empowerment is a drive towards the realization of the innate potentials found in an individual employee. Thus the potentials found in an employee can be enhanced if empowered. The scholar further opined that, one of the three basic measures of employee's empowerment is the ability to have access to resources needed for a decent standard of living, ability to live a long and healthy life and the ability to be knowledgeable which can be achieved via training as one of the indicators of empowerment. 
Abiodun-Oyebanji (2010) argued that most state owned universities for instance appear to have challenge with the empowerment and service delivery of their academic staff, due to their poor funding and deplorable state of facilities when compared with their counterparts in federally owned universities. In the same vein, Olajuwon (2002) is equally of the opinion that, many of the federal universities seem to be better funded than their state counterparts. This development then seems to have led to a better service delivery of the academic staff in the federal universities. However, with the current poor or ailing state of Nigerian economy, it is not likely that many public universities are well funded; considering the various agitations of Nigerian academic staff in form of incessant strike actions, crying for proper funding of Nigerian Universities. Apart from this, many universities managers have also been blamed for mismanaging the available fund at their disposal, to do the needful; including the empowerment of academic staff for better service delivery.

Every organization needs to adopt some kind of empowerment initiatives for at least part of their work force in order to be successful in today's business environment so as to be able to tap the employees' knowledge, ideas, energy, and creativity among others. The best organizations accomplish this by empowering their employees to take initiative without prodding, serving the collective interest of the organization without being micro managed; and act like the owners of the organization. Research has shown that when people experience empowerment at work, positive outcomes are likely to occur; they are likely to report less job strain, more job satisfaction and organizational commitment (Olorunsola, 2011). The rate of turnover may also likely be low.

According to Donde (2004), there have been a lot of talk these days about empowering employees (universities academic staff inclusive), and there is an increasing evidence that empowerment is directly linked to improved results. Empowerment practices must therefore be implemented with the hope of building employee commitment, overcoming worker's dissatisfaction and reducing absenteeism, turnover, poor quality work and sabotage with the resultant effect of a better service delivery on the parts of employees (academic staff inclusive).

Academic staff empowerment could then be described as giving academic staff a certain degree of power or authority to act or to equip with power to function in line with the performance of their specific functions of teaching, research and community service without inhibitions. It entails equipping and motivating academic staff to do what is expected of them. It is the process of enhancing or stimulating academic staff morale and actions towards giving their all, in contributing to the achievement of university goals and that of the nation at large. In empowering academic staff, the management may deploy the tools of training, promotion, incentives, job recognition, and job security among others. Therefore, the degree at which teaching, research and community service are effectively carried out may depends on the level at which academic staff are trained, promoted, granted incentives, recognized and also secured on their jobs.

Audu (2015) however noted that, what empowers one employee may not function as an empowering tool for the other. Therefore an organization must identify and stipulate the various mechanisms that could enhance employee's performance. There are basically many ways through which academic staff could be empowered in order to make them effective, efficient, responsible and responsive to the needs of the university and the society at large. Some of these include; job recognition, promotion, given incentives, training, and job security among others. This then suggests, according to Ogunyemi (2013) that, academic staff are the catalysts in any school system (university system inclusive) and the level of encouragement and support they receive from the management, government or other players in the process would progressively or adversely affect their service delivery or performance and subsequently the productivity of the system.

Abiodun-Oyebanji (2010) and Ogunyemi (2013) argued further that, academic staff holds the key to the success of the university system and all elements within the system are only useful to the extent by which the academic staff breathes life into them because they are the lubricant or life wires of the system. Hence, their empowerment for better performance must not be handled with kids' glove or relegated to the background otherwise, the nation's aspiration of using university education as a tool for national development would ever remain a mirage.

Job recognition as one of the indices of empowerment is the identification or acknowledgement given for something. According to Abiodun- Oyebanji and Adekola (2016), it is the timely, informal or formal acknowledgement of a person's or team's behaviour, effort or business result that support the organization's goals and values, and which has clearly been beyond normal expectations. One of the most central tasks within the human resource function deals with the development of the effective and efficient compensation and recognition program (s). Therefore, academic staff must be recognized and rewarded for their good works and contributions to the university system as this may increase their level of productivity, thus, enhancing their service delivery especially in the face of unfavourable working conditions militating against their works.

Promotion is another tool for empowering academic staff in Nigerian universities. Hierarchy of needs theory by Abraham Maslow (1943) emphasized the various levels of human needs which may jeopardize productivity if not met; especially at a minimal level. Academic staff should therefore be empowered to deliver their academic responsibilities with the aim of getting to the zenith of their profession through promotion as and when due. Delay in the promotion of academic staff as the case seems to be in many Nigerian universities may 
endanger their effective service delivery.

Given incentive is equally a key tool in empowering academic staff to enhance their service delivery. In the work of Audu (2015) and Abiodun-Oyebanji and Adekola (2016), incentives could be in form of pay, bonus, allowances, among other benefits and opportunities. According to Elumah, Ibrahim and Shobayo (2016), Incentives are designed to encourage performance of employees, regardless of the form of incentives, it plays an important role in promoting employees' capacity and moving abilities, it motivates employees to develop their skills, abilities and balance between organization requirements and the individuals' needs which may improve the organization performance effectively and efficiently. According to Ogunyemi (2013), teachers' (academic staff inclusive) welfare consists of care, encouragement or support given to enhance their performance in the discharging of their multifarious responsibilities. Empowering academic staff is hence very critical to their degree of commitment, social, physical and psychological well being in the system.

Training is another means of empowering academic staff to achieve better delivery of their service. Akinwumi (2000) opined that staff training is an organized system to boost the acquisition of wider and new knowledge and to develop further, the skill and techniques to function effectively on the job. According to the scholar, training is perhaps one of the best known techniques of manpower development. It means orientating a worker towards the needs of the organization, for the purpose of maximum output and attainment of the organizational goals and objectives. The absence of adequate staff training for academic staff in Nigerian universities may reduce the quality of the service rendered by them. Consequentially, its timely presence may result in an increased and better delivery of service.

Job security is the protection against job loss. This is another tool of empowering the work of academic staff. It is a means of motivating staff members to work. However, research over the years has generated wide empirical evidences about the negative impact of a job lost on a number of aspects related both to individuals' well being and to organizational functioning. For instance, the extent at which an academic staff feel secured on the job, specifically as it concerns retirement may influence their performance in the areas of teaching, research and community service. Therefore, to avert psychological imbalance which might result to poor service delivery, academic staff should enjoy a significant degree of job security.

However, It seems many of the elements or indicators of empowerment captured in the study are absent in many Nigerian universities due to poor funding. Yann (2002) buttressed this further that, many state owned universities established in early 1980s had become moribund; according to him, many of them today are operating as a second class teaching institutions, due to poor funding.

Good pay packet, good cordial relationship among workers and their boss. Promotion, training, job recognition among others appear very critical to better service delivery of academic staff in Nigerian universities. The above position is in agreement with Virgy (2007) and Abiodun- Oyebanji (2010) works that, adequate empowerment of staff in work place would go a long way in determining their service delivery. Ogunyemi (2013) equally laid credence to this that educational quality is largely a function of the interface of input and process variables within a given environment. Teachers are the anchors for facilitation of these variables and their activities on a daily basis go a long way in ensuring the functionality of the entire education system (university inclusive). Teachers' ability to deliver on this mandate however depends largely on the extent to which they are empowered for service. Considering therefore the critical roles of staff empowerment in achieving good workers service delivery in an organization (university system inclusive), this study therefore investigated the influence of academic staff empowerment on service delivery in Nigerian universities.

\section{Statement of Problem}

Over the years, the performance of academic staff in Nigerian universities has been on decline and this seems to affect their service delivery. The assumed poor performance of academic staff have been attributed to a number of factors, which include lack of empowerment packages such as training, promotion, job recognition, incentives and job security among others, which manifest itself in-poor performance, pre-mature departure from the system and lack of job commitment. Some academic staff had sought for greener pastures in other sectors such as oil companies, banking, and production industries, even abroad where salaries, fringe benefits and general conditions are far better. Lacks of training, promotion, incentives, recognition, job security among others appear to be some of the crucial factors responsible for frustration and eventual decline in the delivery of service of Nigerian universities academic staff. The implication of all these is that, the lack of empowerment of academic staff could lead to so many other problems within the university system ranging from high rate of academic staff indiscipline, low academic staff morale, incessant strike actions and invariably poor academic staff service delivery, to mention but a few. As such, academic staff development and empowerment need to be enhanced for better service delivery, and hence the reason for carrying out this study.

\section{Research Hypotheses}

The following hypotheses were formulated to guide the study: 
1. There is no significant relationship between the relative effects of Academic Staff empowerment (Training, promotion, incentive, recognition and job security) and service delivery in Nigerian universities.

2. There is no significant relationship between the composite effect of Academic Staff empowerment (Training, promotion, incentive, recognition and job security) and service delivery in Nigerian universities.

3. There is no significant difference between federal and state universities in terms of academic staff empowerment.

4. There is no significant difference between federal and state universities in terms of academic staff service delivery.

\section{Methodology}

The study adopted descriptive survey research design. The population of this study was all the academic staff of the University of Ibadan and Lagos State University, Nigeria, which are both federal and state universities respectively. The sample of the study consisted of the 150 academic staff randomly selected from each of the two sampled universities through simple random sampling technique; to make a total sample of 300 samples. The research instrument of the study was a validated questionnaire titled "Academic Staff Empowerment and Service Delivery in Nigerian Universities"' (ASEASD). The reliability of the instrument yields a cronbach's coefficient value of 0.82 which made it reliable. Multiple regressions and independent t-test were used to test the hypotheses formulated.

\section{Presentation and Analysis of Results}

\section{Research Hypotheses}

Hypothesis 1: There is no significant relationship between the relative effects of academic staff empowerment (Training, Promotion, Incentive, Job Recognition and Job Security) and service delivery in Nigerian universities.

Table 1: Relative Effects of Academic Staff Empowerment on Service Delivery in Nigerian Universities.

\begin{tabular}{|l|r|r|r|r|r|}
\hline \multirow{2}{*}{ Model } & \multicolumn{2}{|c|}{ Unstandardized Coefficients } & Standardized Coefficients & \multirow{2}{*}{ T } & Sig. \\
\cline { 2 - 6 } & \multicolumn{1}{|c|}{$\mathrm{B}$} & Std. Error & Beta & & \\
\hline (Constant) & 1.051 & .693 & .025 & .632 & .131 \\
\hline Training & .027 & .043 & .228 & 5.049 & .000 \\
\hline Promotion & .262 & .052 & .158 & 3.173 & .002 \\
\hline Incentive & .158 & .050 & .348 & 8.326 & .000 \\
\hline Job recognition & .400 & .048 & .252 & 4.979 & .000 \\
\hline Job security & .270 & .054 & & \\
\hline
\end{tabular}

Dependent Variable: Service Delivery

Table 1 shows the predictions of each of the independent variables and only four out of five independent variables is shown to have significant prediction $(\mathrm{p}<0.05)$. Job recognition has the highest prediction $(\beta=0.348$; $\mathrm{t}=8.326 ; \mathrm{p}<0.05)$; followed by job security $(\beta=0.252 ; \mathrm{t}=4.979 ; \mathrm{p}<0.05)$, promotion $(\beta=0.228 ; \mathrm{t}=5.049$; $\mathrm{p}<0.05)$ and incentive $(\beta=0.158 ; \mathrm{t}=3.173 ; \mathrm{p}<0.05)$. Training has no significant relative prediction to service delivery in Nigerian universities. It can then be concluded that job recognition, job security, promotion and incentive make a significant contribution to the academic staff service delivery in Nigerian universities. However, Job recognition is a more potent predictor.

Hypothesis 2: There is no significant relationship between the composite effect of academic staff empowerment (training, promotion, incentive, job recognition and job security) and service delivery in Nigerian universities.

Table 2: Composite Contribution of Academic Staff Empowerment to Service Delivery in Nigerian Universities

\begin{tabular}{|l|l|r|r|r|r|c|}
\hline \multicolumn{1}{|c|}{ REGRESSION } & \multicolumn{5}{|c|}{ ANOVA $^{\mathbf{a}}$} \\
\hline \multicolumn{1}{|c|}{ Model } & & Sum of Squares & \multicolumn{1}{c|}{ Df } & \multicolumn{1}{c|}{ Mean Square } & F & Sig. \\
\hline $\mathbf{R}=\mathbf{8 3 2}$ & Regression & 919.868 & 5 & 183.974 & 132.310 & $.000^{\mathrm{b}}$ \\
\cline { 2 - 7 } \\
$\mathbf{R}$ Square $=\mathbf{. 6 9 2}$ & Residual & 408.799 & 294 & 1.390 & & \\
\cline { 2 - 8 } \\
\cline { 2 - 7 }
\end{tabular}

a. Dependent Variable: Service Delivery

b. Predictors: (Constant), training, promotion, incentive, job recognition and security

The results in table 2 indicated that, with all the predictor variables (training, promotion, incentive, job recognition and job security) entered into the regression model at once, there was a significant prediction of service delivery $\left(\mathrm{R}=.832 ; \mathrm{R}^{2}=.692 ;\left(\mathrm{F}_{(5,294)}=132.310 ; \mathrm{p}<.05\right)\right.$. This showed that all the variables (training, promotion, incentive, job recognition and job security) accounted for $68.7 \%$ of the variance in service delivery. The remaining 31.3\% might be captured by other exogenous variables that were not included in the model. Based on this analysis, training, promotion, incentive, job recognition and job security jointly contributed to academic staff service delivery. 


\section{Hypothesis 3}

There is no significant difference between federal and state universities in terms of academic staff empowerment Table 3: t-test Comparison of Academic Staff Empowerment in Federal and State Universities

\begin{tabular}{|c|c|c|c|c|c|c|c|}
\hline Universities & $\mathbf{N}$ & Df & Mean & Std deviation & $\mathbf{t}$ & Sig & Remark \\
\hline Federal University & 150 & \multirow[t]{2}{*}{298} & 49.95 & 6.340 & \multirow[t]{2}{*}{1.686} & \multirow[t]{2}{*}{.003} & \multirow[t]{2}{*}{ Sig } \\
\hline State University & 150 & & 48.76 & 5.509 & & & \\
\hline
\end{tabular}
$\mathrm{P}<0.05$

Independent t-test was used to examine universities difference in academic staff empowerment. The result revealed that, there was significant difference in academic staff empowerment $(\mathrm{t}(\mathrm{df}=298)=0.003, \mathrm{p}<.05)$. This implies that the mean of federal universities (mean $=49.95, \mathrm{SD}=6.340$ ) is significantly different from or higher than the mean of states universities (mean $=48.76, \mathrm{SD}=5.509$ ). Therefore, the null hypothesis was rejected. The result found that there was a significant difference between academic staff empowerment in federal and state universities.

\section{Hypothesis 4}

There is no significant difference between federal and state universities and academic staff service delivery

Table 4: t-test Comparison of Academic Staff Service Delivery in Federal and State Universities

\begin{tabular}{|l|l|l|l|l|l|l|l|}
\hline Universities & $\mathbf{N}$ & $\mathbf{D f}$ & Mean & $\begin{array}{l}\text { Std. } \\
\text { deviation }\end{array}$ & $\mathbf{t}$ & Sig & Remark \\
\hline Federal University & 150 & 298 & 16.46 & 2.144 & 1.041 & .004 & Sig \\
\hline State University & 150 & & 14.207 & 2.071 & & \\
\hline
\end{tabular}

$\mathrm{P}<0.05$

Independent t-test was used to investigate universities difference in academic staff service delivery. The result indicated that, there was significant difference in academic staff service delivery $(\mathrm{t}(\mathrm{df}=298)=0.004, \mathrm{p}$ $<.05)$. This implies that the mean of federal universities (mean=16.46, $\mathrm{SD}=2.144$ ) is significantly different from that of state universities (mean $=14.207, \mathrm{SD}=2.071$ ). Therefore, the null hypothesis was rejected. The results revealed that there was a significant difference between academic staff service delivery in federal and state universities.

\section{Discussion of Findings}

The finding of the study showed a significant relative and composite contributions of academic staff empowerment to service delivery; these findings were consistent with the works of Virgy (2007), AbiodunOyebanji and Adekola (2016), Elumah and Shobayo (2016) who all affirmed that, empowerment of workers (academic staff inclusive) plays a critical role in enhancing employees capacity, skills and moving abilities; which invariably may lead to efficient and effective organizational performance or service delivery.

On the results of significant difference in the academic staff empowerment and service delivery in both the federal and state universities, the findings were in line with the works of Olajuwon (2002) and AbiodunOyebanji (2010) who found out that, the academic staff in federal universities were more empowered and hence, they tend to perform their duties better than their counterparts in the state universities. The findings may be as a result of the better funding of the federal universities when compared with their counterparts at the state level, who have to depend on the merger monthly subventions from their state governments before they could run their universities. Many of these state universities owned their staff backlog of salaries and allowances due to the failure of their various state governments to regularly pay their monthly subvention. As at the time of carrying out this study, there are cases of state universities in Nigeria who have not received their subvention for the past six or nine months from their various state government. This may makes it grossly impossible for many of the managements of these state universities to empower their staff, especially the academic staff for better service delivery.

\section{Conclusions and Recommendations}

From the findings of this study, it can be concluded that, Job recognition is a more potent predictor of academic staff service delivery in Nigerian universities. However, promotion, incentive, and job security equally made significant contributions to service delivery except training that made a low contribution. Hence, close attention should be paid to these variables in the Nigerian universities system as effective tools for empowering academic staff for better service delivery. Also state universities should seek for alternative ways of funding their universities so as to facilitate the empowerment of their academic staff for better service delivery; rather than depending solely on government subvention that are not regularly paid. Based on the findings, discussions and conclusion drawn from this study, it was recommended that university management should not only recognize the jobs of academic staff, but also should ensure that those who need promotion, incentives as well as job security, even training, are accorded the same promptly so as to enhance or boost their service delivery. Efforts should be put in place also by the university management to keep on improving academic staff empowerment for 
sustainable service delivery.

\section{References}

Abiodun-Oyebanji, O. J. (2010), "Resource situation and academic staff job performance in south-west Nigerian universities", PhD Thesis, Faculty of Education, University of Ado-Ekiti, Nigeria.

Abiodun-Oyebanji, O.J. (2014), “Employers of labour's perception of employability of Nigerian university graduates", Journal of Education Review 7(1), 102-104 India; Serials publications.

Abiodun-Oyebanji, O. J . and Adekola, H.A (2016), "Welfare package factors and job commitment of administrative staff of the Polytechnic Ibadan, Nigeria", Journal of Sociology and Education in Africa 14(1), 61-70. Uganda

Abosede, S.C. (2013), "Educational Empowerment of Nigerian women: Prospects and Limitations. In P.K Ojedele (Eds). Challenges of Educational Development in Nigeria Ondo", NIEPA Publication.

Adelekan, O.K. (2018), "Retention strategies and productivity of Academic staff in universities in Southwestern Nigeria", Unpublished PhD Thesis, Faculty of Education,University of Ibadan, Nigeria.

Akinwumi, F. S. (2000), "Impact of motivation and supervision on teachers productivity in secondary schools in Oyo State", Unpublished PhD Thesis, University of Ibadan.

Audu J. S. (2015), "The Colossus of Rewards and Motivation on Employees Performance In Kogi State University, Ayungba," International Journal of Public Administration and Management Research (IJPAMR); 2(5), 85-94.

Awamleh, N.A (2013), "Enhancing employee performance via empowerment : A field survey" Asian Journal of Business Management, 5(3), 313-319

Ayeni, A.O., Jaiyeoba, A.O., and Atanda, A.I. (2008), "Infrastructural facilities and productivity of academic staff of University of Ibadan, Ibadan, Nigeria", Nigerian Journal of Educational Administration and Planning (NJEAP), 8(1), 197-213

Byars, L.L, and Rue L.W. (2006),"Human Resource Management; New York", The McGraw-Hill.

Clutterbuck, I.D. (1994), "The power of empowerment: Release the hidden talents of your employees," London: Kongo page

Don de Guerre (2004), "Introduction to the special Issue on Employee Empowerment," The public Sector Innovation Journal, 9(1), 1-5

El-Rufai, N.A. (2013), “The Accidental Public Servant”, Ibadan: Safari Books.

Elumah, .I, and Shobayo (2016), "The Impact of Financial and Moral Incentives on Organizational Performance a Study of Nigerian Universities," Arabian Journal of Business and Management Review, 6 (5).

Federal Republic of Nigeria (2014), "National Policy on Education," $6{ }^{\text {th }}$ edition NERDC Lagos, Nigeria

Lowe, Graham (2001), "Employer of choice workplace innovation government: A synthesis report", Ottawa:CPRN/

Maslow, A.H. (1943), “A preface to motivational theory”' Psychosomatic medicine, 85-89.

Ogunyemi, B. (2013), "Teachers welfare: catalyst for qualitative and functional secondary education" in P.K Ojedele (Ed). Challenges of Educational Development in Nigeria Ondo: NIEPA Publication

Olajuwon, O. T. (2002), "Education in Nigeria: A futuristic perspective" : Paper Presented at the Central Educational Services, Lagos, Nigeria.

Olorunsola, O. (2011), "Job satisfaction and commitment of non- academic staff of university of Ado-Ekiti, Nigeria", PhD Thesis, University of Ado-Ekiti.

Sunday, A.O. (2017), "Employee Job Satisfaction in Nigerian Tertiary institution: A Comparative Study of Academic Staff in Public and Private Universities" Global Journal of Human Resource Management; 5(4), 33-46, Published by European Centre for Research Training and Development, UK.

Upev, C. and Idachaba (2015), "The Effects of Motivation on Staff Productivity at the Francis Sulemanuu Idachaba Library, University of Agriculture Makurdi," Nigerian Journal of Research and Method in Education 5(2), 10 -17

Virgy, O. (2007), "Interpersonal skills, for effective personnel administration", Laos: Vitaman Educational Books.

Yann, L. (2002), "Extraversion strategy in marginalized institutions. Nigerian academics' responses to changing patterns in international research needs and practices", Consortium of higher education researchers. $15^{\text {th }}$ Annual Conference, 5-7 Sept. Vienna, Austria. 